\title{
THE WARS \\ OF THE ROSES
}




\section{British History in Perspective \\ General Editor: Jeremy Black}

PUBLISHED TITLES

D. G. Boyce The Irish Question and British Politics 1868-1986

A. J. Pollard The Wars of the Roses

Robert Stewart Party and Politics, 1830-1852

FORTHCOMING TITLES

C. J. Bartlett British Foreign Policy in the Twentielh Century

John Davis British Politics 1885-1931

John Derry British Politics in the Age of Pilt

Ann Hughes Causes of the English Civil War

Diarmaid MacCulloch Religion and Society 1547-1603

Michael Prestwich English Politics in the Thirteenth Century 


\title{
THE WARS \\ OF THE ROSES
}

\author{
A. J. Pollard \\ Principal Lecturer in History \\ Teesside Polytechnic
}

Macmillan Education 
(C) A. J. Pollard 1988

Softcover reprint of the hardcover 1st edition 1988

All rights reserved. For information, write:

Scholarly \& Reference Division,

St. Martin's Press, Inc.,

175 Fifth Avenue, New York, NY 10010

First published in the United States of America in 1988

ISBN 978-0-333-40604-5 ISBN 978-1-349-19549-7 (eBook)

DOI 10.1007/978-1-349-19549-7

Library of Congress Cataloging in

Publication Data applied for. 


\section{CONTENTS}

Preface vii

Map and tables viii

$\begin{array}{ll}\text { Introduction } & 1\end{array}$

1 The Wars in History 5

2 The Course of the Wars 20

Prelude to the wars: 1450-59 20

The first wars: 1459-71 24

The second wars: 1483-87 33

Summary: the character of the wars $\quad 40$

3 The Causes of the Wars 45

Long-term causes of the first wars $\quad 46$

Short-term causes of the first wars $\quad 53$

Immediate causes of the first wars $\quad 62$

The causes of the second wars 66

4 The Scale of the Wars 74

The wars and English society $\quad 74$

$\begin{array}{ll}\text { The wars and European politics } & 90\end{array}$ 
5 Aftermath and the Wider Context of the Wars 95

The restoration of royal authority $\quad 95$

England's neighbours 104

$\begin{array}{ll}\text { Conclusion } & 111\end{array}$

References 114

Select Bibliography 126

Glossary 131

$\begin{array}{ll}\text { Index } & 133\end{array}$ 


\section{PREFACE}

This work is a discussion of what seem to me to be the important and distinctive characteristics of the Wars of the Roses. It is founded upon and reflects the work of many scholars and has had the advantage of many hours of discussion with friends and colleagues too numerous to name. On some issues it agrees with them, on others it disagrees. Any strengths it possesses owes much to them, the weaknesses are all my own. I would however like to record a special debt to the late Charles Ross, whose book under the same title will for long remain the best introductory work on the subject. And I would like to thank Jill Wren for her patient assistance in preparing the typescript for publication.

Taunton

September, 1987

For Richard and Edward 
England during the Wars of the Roses

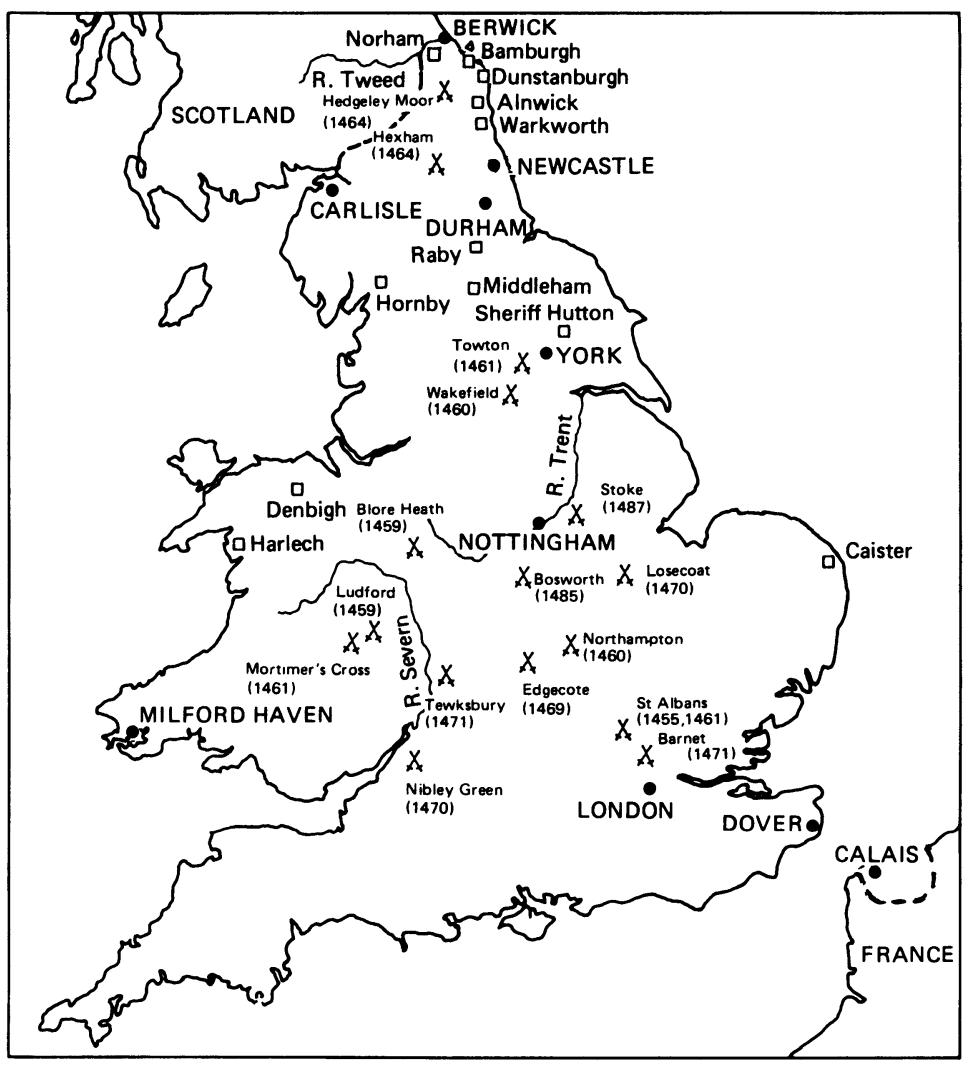

X Battles $\quad$ TOWNS $\square$ Castles 


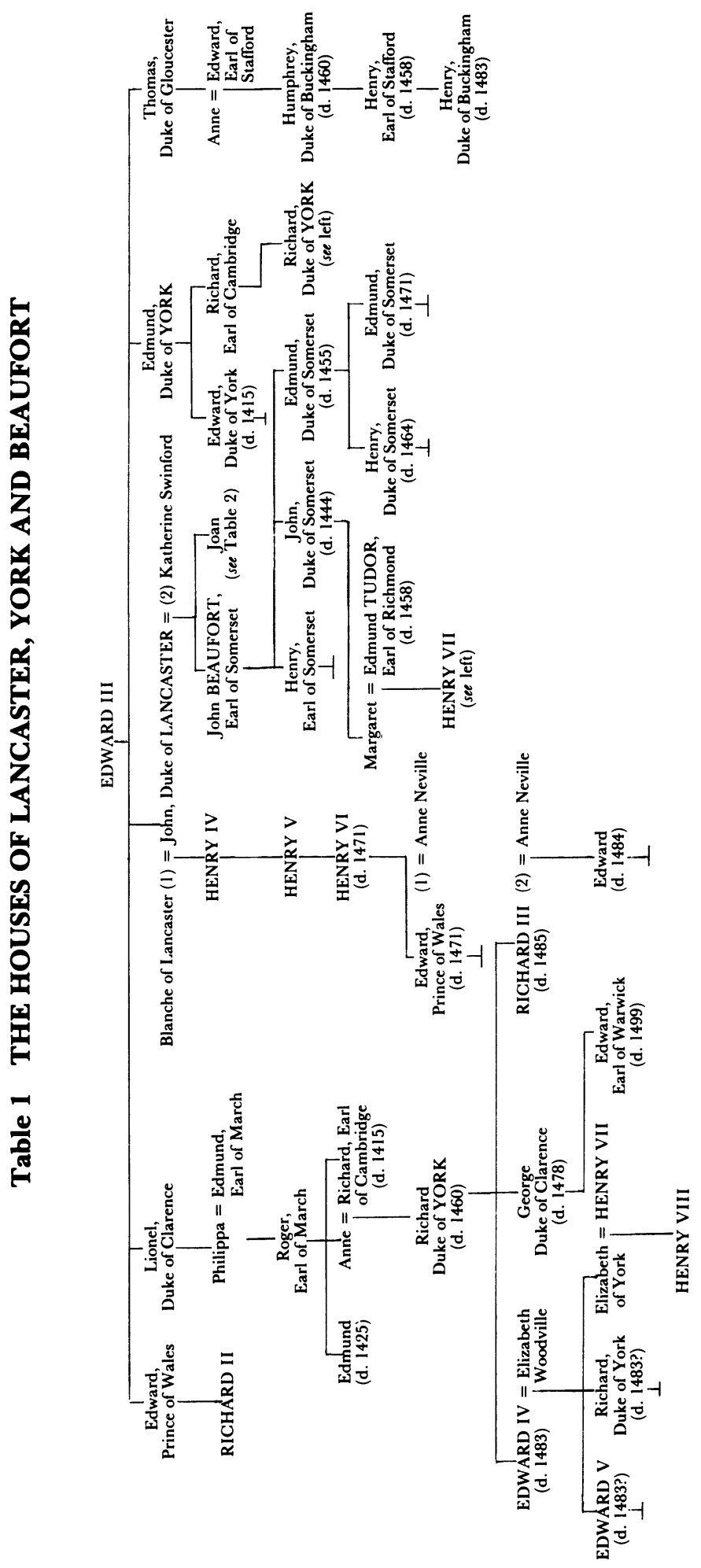




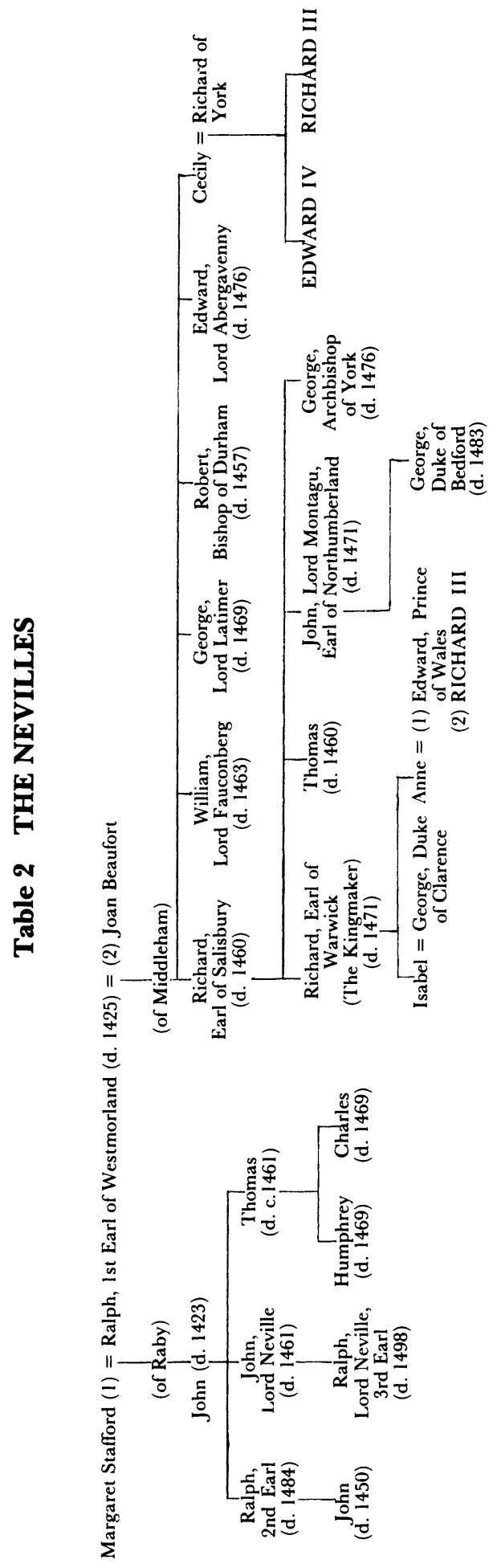

